\title{
Serum enzyme levels in patients with myasthenia gravis after aerobic and ischaemic exercise ${ }^{1}$
}

\author{
JERRY KOLINS AND JOHN GILROY \\ From the Department of Neurology, Wayne State University, \\ Harper Hospital, Detroit, Michigan, U.S.A.
}

SUMMARY This study was designed to test the hypothesis that there is a myopathic component in myasthenia gravis. Serum enzyme analyses and lactate and pyruvate assays were undertaken before and after exercise in order to detect possible leakage from defective muscle membrane. A patient and a control group were exercised under (1) aerobic conditions, (2) ischaemic conditions, and (3) aerobic conditions under the influence of edrophonium chloride. The patient group showed a higher resting level of lactate in the aerobic state than did the controls. In addition, the average change in SGOT values in the patient group after one minute of aerobic exercise under the influence of edrophonium chloride exceeded that of the control group. Both these findings suggest possible leakage of enzyme and metabolite from the myasthenic muscle due to a membrane defect and support the hypothesis that there may be a myopathic component in myasthenia gravis. However, the two groups showed no significant differences in CPK values, which are often elevated in primary muscle diseases.

Several possible causes of myasthenia gravis have been described (Herrmann, 1967): (1) autoimmunity, in which the body develops antibodies against its own muscle; (2) the presence of a neuromuscular blocking agent at the postsynaptic membrane; (3) a defect in production of liberation of acetylcholine at the presynaptic membrane; and (4) a slow virus infection with long latency and low virulence.

The demonstration of muscle binding antibodies in the serum of some patients with myasthenia gravis by Strauss, Seegal, Hsu, Burkholder, Nastuk, and Osserman in 1960 has been confirmed in other laboratories, giving support to the concept of myasthenia gravis as an autoimmune disease (Downes, Greenwood, and Wray, 1966; Simpson, 1966b). These antibodies have an affinity for the I-band in striated muscle (McFarlin, Engel, and Strauss, 1966) and it has not been possible to show any binding of antibodies at the myoneural junction (Strauss and Kemp, 1967). This suggests that the hypothesis of a progressive failure in neuromuscular transmission as the cause of myasthenia gravis may not be correct and that the fault may be at other sites in the neuromuscular complex (Dameshek,

1 Supported by a grant from the Myasthenia Gravis Association of Detroit, Michigan.
1965). It has been shown by Namba and Grob (1968) that serum and serum globulin fron patients with myasthenia gravis do not inhibit neuromuscular transmission. In fact, this stude attributes a protective rather than a harmful role $N$ to striation binding globulin. The presence of serum antibodies within the muscle fibre suggests that there may be a functional defect within the fibre. There has, however, been little experimental work designed to test this hypothesis.

It is possible that the presence of antibodies might alter or interfere with muscle fibre metabolism, which might produce alterations in the levels of serum enzymes obtained in venous blood from patients with myasthenia gravis. Hess (1965) has demonstrated a moderate decrease in phosphorylase activity in muscle obtained from patients with myasthenia gravis and Hess, MacDonald, Frederick, Jones, Neely, and Gross (1964) reported that creatine phosphokinase (CPK) levels were normal in this disease, although one of their patients showed a significant elevation of the enzyme in the serum. Simpson (1966a) studied the serum enzyme levels of glutamic pyruvic transaminase, glutamic oxalacetic transaminase, aldolase, and CPK. He found no significant elevation of these enzymes in the 22 myasthenic patients studied. We have 
been unable to trace further reports on serum enzyme levels in the American or European literature but a report of serum enzyme activity has appeared in the Russian literature. Perelman and Matlina (1957) have shown that serum of patients with myasthenia gravis depressed the process of phosphocreatine formation in rat muscle to a greater degree than the serum of healthy controls.

The measurement of serum enzyme levels in patients with myasthenia gravis would seem to be of value for two reasons: (1) abnormalities may reflect an interference with muscle metabolism which could only be interpreted as a fault arising within the muscle cell; and (2) abnormal elevation of serum enzymes might indicate a fault in the function of the muscle membrane allowing a 'leak' of enzymes to occur. This would be a positive indication of a primary fault within the muscle fibre in this disease.

\section{METHODS}

Two groups of subjects were used in this investigation: (1) a group of patients with myasthenia gravis; and (2) a group of control subjects with no known muscle disease. Both groups were examined in a similar fashion. A small bore polyethylene catheter was placed in the antecubital vein to permit withdrawal of serial blood samples. Blood samples were taken at rest $\left(\mathrm{E}_{0}\right)$ and exactly one minute after the beginning of exercise $\left(E_{1}\right)$. The patient exercised under aerobic and ischaemic conditions by repeatedly squeezing a sphygmomanometer bulb one time per second until complete fatigue. The amount of air expressed from the bulb was recorded by an ergograph.

The subject was initially asked to squeeze the sphygmomanometer bulb under aerobic conditions - that is, without an inflated blood pressure cuff on his arm. A sample was drawn before work commenced $\left(E_{0}\right)$ and exactly one minute later $\left(E_{1}\right)$. The subject then rested for 20 minutes. Fifteen patients and five controls were tested (Table 1).

During the second phase of the study the subject was asked to exercise under ischaemic conditions. A resting blood sample $\left(E_{0}\right)$ was drawn before work commenced and then one blood pressure cuff was inflated around the arm and another around the wrist. The cuffs were usually inflated to $175 \mathrm{mg} \mathrm{Hg}$ but were always inflated above the level of the systolic blood pressure to insure an ischaemic state. At this point the subject began ischaemic exercise. All patients and controls fatigued one minute \pm 15 seconds after commencement of exercise. The cuffs remained inflated for exactly three minutes after fatigue was reached. At this time, the upper cuff was deflated and blood was drawn without stasis from the antecubital vein $\left(E_{3}\right)$. Seven minutes later $(10$ minutes after fatigue), another sample was drawn $\left(E_{10}\right)$. The lower cuff was deflated and removed. The subject then rested for 20 minutes (Table 2).

TABLE 1

SERUM ANALYSES OF SUBJECTS AT INTERVALS OF ZERO $\left(\mathrm{E}_{0}\right)$ AND ONE $\left(\mathrm{E}_{1}\right)$ MINUTE OF AEROBIC EXERCISE

\begin{tabular}{|c|c|c|c|c|c|c|c|c|c|c|c|c|c|c|}
\hline \multirow[b]{2}{*}{ Subjects } & \multicolumn{2}{|c|}{$\begin{array}{c}C P K \\
(m u / m l .)\end{array}$} & \multicolumn{2}{|c|}{$\begin{array}{c}S G O T \\
(m u / m l .)\end{array}$} & \multicolumn{2}{|c|}{$\begin{array}{c}S G P T \\
(m u / m l .)\end{array}$} & \multicolumn{2}{|c|}{$\begin{array}{c}L D H \\
(m u / m l .)\end{array}$} & \multicolumn{2}{|c|}{$\begin{array}{l}\text { Aldolase } \\
(\mathrm{mu} / \mathrm{ml} .)\end{array}$} & \multicolumn{2}{|c|}{$\begin{array}{c}\text { Lactate } \\
(\mathrm{mg} / 100 \mathrm{ml} .)\end{array}$} & \multicolumn{2}{|c|}{$\begin{array}{c}\text { Pyrucate } \\
(\mathrm{mg} / 100 \mathrm{ml} .)\end{array}$} \\
\hline & $E_{0}$ & $E_{1}$ & $E_{0}$ & $E_{1}$ & $E_{0}$ & $E_{1}$ & $E_{0}$ & $E_{1}$ & $E_{\mathrm{o}}$ & $E_{1}$ & $E_{0}$ & $E_{1}$ & $E_{0}$ & $E_{1}$ \\
\hline \multicolumn{15}{|l|}{ Patients } \\
\hline S.B. & 8.9 & $8 \cdot 0$ & $5 \cdot 9$ & $10 \cdot 8$ & $7 \cdot 4$ & $8 \cdot 3$ & $51 \cdot 6$ & $52 \cdot 1$ & - & - & $7 \cdot 9$ & $11 \cdot 8$ & 0.81 & 0.81 \\
\hline J.B. & $18 \cdot 2$ & 10.6 & $9 \cdot 1$ & $6 \cdot 1$ & $5 \cdot 0$ & $4 \cdot 3$ & $56 \cdot 6$ & 70.4 & - & - & $10 \cdot 1$ & $18 \cdot 2$ & 0.78 & 1.04 \\
\hline E.T. & $17 \cdot 0$ & $17 \cdot 9$ & $11 \cdot 6$ & $5 \cdot 3$ & $4 \cdot 9$ & $8 \cdot 0$ & $46 \cdot 4$ & $38 \cdot 7$ & - & - & $12 \cdot 6$ & $24 \cdot 4$ & $1 \cdot 42$ & $1 \cdot 55$ \\
\hline C.G. & $52 \cdot 1$ & $56 \cdot 1$ & $11 \cdot 8$ & $7 \cdot 0$ & - & $9 \cdot 0$ & $52 \cdot 1$ & $58 \cdot 8$ & - & - & 13.6 & $42 \cdot 0$ & 1.06 & $1 \cdot 58$ \\
\hline M.C. & $8 \cdot 4$ & $5 \cdot 3$ & $9 \cdot 7$ & $11 \cdot 0$ & $4 \cdot 2$ & $9 \cdot 1$ & $57 \cdot 8$ & $60 \cdot 4$ & - & - & $10 \cdot 1$ & $19 \cdot 3$ & 0.69 & 1.06 \\
\hline W.R. & $12 \cdot 6$ & $16 \cdot 6$ & $7 \cdot 0$ & $12 \cdot 1$ & $18 \cdot 2$ & $17 \cdot 3$ & $38 \cdot 2$ & 33.0 & - & 一 & $13 \cdot 4$ & $37 \cdot 0$ & $1 \cdot 18$ & 1.53 \\
\hline S.N. & $32 \cdot 5$ & $29 \cdot 8$ & 22.6 & - & $6 \cdot 1$ & - & $84 \cdot 6$ & $95 \cdot 1$ & 10.7 & - & $18 \cdot 9$ & $21 \cdot 7$ & $1 \cdot 29$ & $1 \cdot 39$ \\
\hline R.Z. & $9 \cdot 5$ & $7 \cdot 1$ & $2 \cdot 7$ & $5 \cdot 5$ & $14 \cdot 1$ & $11 \cdot 1$ & $9 \cdot 8$ & $42 \cdot 4$ & $1 \cdot 8$ & $19 \cdot 1$ & - & - & - & - \\
\hline R.S. & $136 \cdot 2$ & $129 \cdot 7$ & $23 \cdot 1$ & $38 \cdot 0$ & $14 \cdot 8$ & 13.6 & 81.4 & 92.8 & $9 \cdot 3$ & $11 \cdot 6$ & $17 \cdot 1$ & $44 \cdot 1$ & $1 \cdot 42$ & $2 \cdot 17$ \\
\hline W.E. & $207 \cdot 4$ & $251 \cdot 8$ & $21 \cdot 7$ & $27 \cdot 9$ & $11 \cdot 0$ & $12 \cdot 4$ & $88 \cdot 6$ & $72 \cdot 4$ & 9.9 & 13.0 & $8 \cdot 3$ & $31 \cdot 2$ & 0.82 & $1 \cdot 58$ \\
\hline J.N. & $81 \cdot 8$ & $81 \cdot 2$ & $19 \cdot 2$ & 23.6 & $13 \cdot 1$ & $16 \cdot 1$ & 73.4 & $66 \cdot 2$ & $9 \cdot 4$ & $15 \cdot 7$ & $17 \cdot 1$ & 28.0 & $1 \cdot 76$ & $2 \cdot 33$ \\
\hline G.K. & 75.0 & $68 \cdot 6$ & 18.0 & $16 \cdot 8$ & - & $12 \cdot 9$ & 115.6 & $90 \cdot 1$ & - & 6.9 & $9 \cdot 9$ & $15 \cdot 9$ & 0.69 & 0.79 \\
\hline G.D. & $16 \cdot 9$ & $21 \cdot 2$ & $22 \cdot 9$ & $21 \cdot 8$ & $13 \cdot 4$ & $13 \cdot 3$ & 66.5 & $70 \cdot 4$ & 5.4 & $8 \cdot 5$ & - & - & - & - \\
\hline F.S. & $35 \cdot 4$ & $32 \cdot 2$ & $24 \cdot 1$ & $26 \cdot 5$ & $39 \cdot 3$ & $36 \cdot 8$ & 80.6 & $66 \cdot 3$ & $7 \cdot 7$ & $9 \cdot 3$ & - & - & - & - \\
\hline C.P. & $66 \cdot 2$ & $53 \cdot 5$ & $18 \cdot 1$ & $19 \cdot 4$ & - & - & $65 \cdot 9$ & $52 \cdot 0$ & $10 \cdot 7$ & $8 \cdot 6$ & - & - & - & - \\
\hline Mean value & $51 \cdot 9$ & $52 \cdot 6$ & $15 \cdot 2$ & 16.6 & $12 \cdot 6$ & $13 \cdot 2$ & $64 \cdot 6$ & $64 \cdot 0$ & $8 \cdot 1$ & $11 \cdot 6$ & $12 \cdot 6$ & $26 \cdot 7$ & $1 \cdot 08$ & $1 \cdot 44$ \\
\hline \multicolumn{15}{|l|}{ Controls } \\
\hline G.H. & $28 \cdot 4$ & 16.6 & - & - & - & $10 \cdot 7$ & $35 \cdot 1$ & $28 \cdot 4$ & - & - & $7 \cdot 0$ & $12 \cdot 4$ & 1.02 & 1.08 \\
\hline H.S. & $32 \cdot 0$ & $37 \cdot 9$ & $12 \cdot 6$ & $14 \cdot 2$ & $9 \cdot 5$ & 12.6 & 41.9 & $37 \cdot 0$ & - & - & $4 \cdot 8$ & $8 \cdot 1$ & $1 \cdot 07$ & $1 \cdot 13$ \\
\hline J.K. & $27 \cdot 7$ & 33.6 & $22 \cdot 2$ & $23 \cdot 1$ & $15 \cdot 0$ & $11 \cdot 5$ & $56 \cdot 2$ & 51.9 & 11.4 & $14 \cdot 7$ & $4 \cdot 8$ & $27 \cdot 0$ & 0.72 & 1.95 \\
\hline F.A. & $79 \cdot 7$ & $80 \cdot 6$ & $18 \cdot 6$ & $24 \cdot 8$ & $13 \cdot 3$ & $14 \cdot 0$ & $18 \cdot 5$ & $72 \cdot 3$ & $10 \cdot 5$ & $12 \cdot 5$ & 4.4 & $22 \cdot 3$ & $1 \cdot 20$ & $1 \cdot 76$ \\
\hline P.S. & $93 \cdot 5$ & $102 \cdot 4$ & $18 \cdot 7$ & $22 \cdot 5$ & $14 \cdot 1$ & $13 \cdot 2$ & $60 \cdot 2$ & $64 \cdot 7$ & $11 \cdot 2$ & $13 \cdot 5$ & $4 \cdot 4$ & $16 \cdot 5$ & 1.01 & $1 \cdot 13$ \\
\hline Mean value & $52 \cdot 3$ & $54 \cdot 2$ & $18 \cdot 0$ & $21 \cdot 2$ & $13 \cdot 0$ & $12 \cdot 4$ & $42 \cdot 4$ & 50.9 & $11 \cdot 0$ & 13.6 & $5 \cdot 1$ & $17 \cdot 3$ & $1 \cdot 00$ & 1.41 \\
\hline
\end{tabular}


TABLE 2

SERUM ANALYSES OF SUBJECTS AT REST $\left(E_{0}\right)$ AND AT THREE $\left(E_{3}\right)$ AND TEN $\left(E_{10}\right)$ MINUTES AFTER FATIGUE OF ISCHAEMIC EXERCISE

\begin{tabular}{|c|c|c|c|c|c|c|c|c|c|c|c|c|c|c|c|}
\hline \multirow{2}{*}{ Subjects } & \multicolumn{3}{|c|}{$\begin{array}{c}C P K \\
(m u / m l .)\end{array}$} & \multicolumn{3}{|c|}{$\begin{array}{c}S G O T \\
(m u / m l .)\end{array}$} & \multicolumn{3}{|c|}{$\begin{array}{c}S G P T \\
(m u / m l .)\end{array}$} & \multicolumn{3}{|c|}{$\begin{array}{c}L D H \\
(m u / m l .)\end{array}$} & \multicolumn{3}{|c|}{$\begin{array}{l}\text { Aldolase } \\
(\mathrm{mu} / \mathrm{ml} .)\end{array}$} \\
\hline & $E_{0}$ & $E_{3}$ & $E_{10}$ & $E_{0}$ & $E_{3}$ & $E_{10}$ & $E_{0}$ & $E_{3}$ & $E_{10}$ & $E_{0}$ & $E_{3}$ & $E_{10}$ & $E_{0}$ & $E_{3}$ & $E_{10}$ \\
\hline \multicolumn{16}{|l|}{ Patients } \\
\hline S.B. & $8 \cdot 2$ & $9 \cdot 8$ & $24 \cdot 5$ & 10.6 & $9 \cdot 3$ & 9.5 & 8.0 & $8 \cdot 5$ & $9 \cdot 5$ & $44 \cdot 8$ & $49 \cdot 8$ & $35 \cdot 7$ & - & - & - \\
\hline J.B. & $27 \cdot 0$ & $23 \cdot 3$ & $17 \cdot 7$ & $2 \cdot 5$ & $6 \cdot 8$ & $6 \cdot 8$ & $4 \cdot 5$ & 6.8 & $4 \cdot 8$ & $45 \cdot 5$ & $60 \cdot 5$ & $62 \cdot 7$ & - & - & 一 \\
\hline E.T. & $12 \cdot 3$ & $12 \cdot 3$ & $13 \cdot 1$ & $5 \cdot 4$ & $8 \cdot 3$ & 8.9 & 6.6 & 4.9 & $7 \cdot 2$ & $35 \cdot 1$ & 52.6 & $32 \cdot 0$ & - & - & - \\
\hline C.G. & 31.6 & $22 \cdot 1$ & $27 \cdot 7$ & $18 \cdot 0$ & - & $22 \cdot 4$ & $10 \cdot 3$ & - & 11.9 & 50.6 & $62 \cdot 4$ & $35 \cdot 1$ & - & - & - \\
\hline M.C. & $22 \cdot 0$ & $17 \cdot 5$ & 20.5 & $13 \cdot 1$ & $12 \cdot 7$ & $13 \cdot 1$ & $9 \cdot 1$ & - & 10.4 & $55 \cdot 7$ & 56.8 & 53.7 & - & - & - \\
\hline W.R. & 5.5 & 12.6 & $11 \cdot 1$ & $6 \cdot 3$ & 8.9 & 11.4 & $16 \cdot 7$ & $18 \cdot 0$ & $21 \cdot 2$ & $23 \cdot 2$ & $20 \cdot 1$ & $24 \cdot 3$ & - & - & - \\
\hline S.N. & $29 \cdot 2$ & 36.6 & $39 \cdot 2$ & $17 \cdot 1$ & $20 \cdot 3$ & $21 \cdot 8$ & 6.6 & 6.6 & 9.8 & 66.6 & $70 \cdot 6$ & $76 \cdot 1$ & 5.8 & $6 \cdot 4$ & $8 \cdot 1$ \\
\hline R.Z. & $2 \cdot 4$ & $5 \cdot 5$ & $16 \cdot 6$ & $5 \cdot 5$ & $14 \cdot 7$ & $4 \cdot 2$ & $15 \cdot 4$ & - & 21.6 & $2 \cdot 6$ & $17 \cdot 0$ & 0.5 & - & - & - \\
\hline R.S. & $128 \cdot 5$ & $142 \cdot 2$ & 126.4 & $23 \cdot 3$ & $27 \cdot 2$ & $23 \cdot 4$ & $10 \cdot 0$ & $11 \cdot 5$ & $9 \cdot 5$ & $70 \cdot 3$ & $77 \cdot 9$ & $68 \cdot 8$ & $9 \cdot 2$ & $8 \cdot 8$ & 8.4 \\
\hline W.E. & 233.6 & $255 \cdot 3$ & 233.7 & $21 \cdot 5$ & $27 \cdot 8$ & $22 \cdot 5$ & $9 \cdot 5$ & $12 \cdot 0$ & $9 \cdot 6$ & $99 \cdot 3$ & $70 \cdot 6$ & 76.0 & $11 \cdot 8$ & $12 \cdot 8$ & $13 \cdot 5$ \\
\hline J.N. & $87 \cdot 3$ & 86.9 & $81 \cdot 7$ & 20.8 & $27 \cdot 8$ & 25.9 & 15.9 & $19 \cdot 4$ & $18 \cdot 3$ & 59.0 & $60 \cdot 6$ & 56.8 & $10 \cdot 8$ & 16.0 & $12 \cdot 1$ \\
\hline G.K. & - & - & - & - & - & - & - & - & - & - & - & - & - & - & - \\
\hline G.D. & - & - & - & - & - & - & - & - & - & - & - & - & - & - & - \\
\hline F.S. & 33.4 & $28 \cdot 7$ & 20.9 & $27 \cdot 2$ & $32 \cdot 6$ & $34 \cdot 0$ & $36 \cdot 1$ & $37 \cdot 6$ & 38.4 & $71 \cdot 0$ & $84 \cdot 1$ & $81 \cdot 6$ & $14 \cdot 2$ & $8 \cdot 0$ & $10 \cdot 4$ \\
\hline C.P. & $66 \cdot 2$ & 63.9 & $61 \cdot 1$ & $17 \cdot 8$ & $24 \cdot 1$ & $32 \cdot 9$ & - & - & - & $56 \cdot 2$ & $59 \cdot 0$ & $78 \cdot 5$ & $5 \cdot 7$ & $10 \cdot 5$ & $13 \cdot 6$ \\
\hline Mean value & $52 \cdot 9$ & $57 \cdot 4$ & $53 \cdot 4$ & $14 \cdot 5$ & 18.4 & $18 \cdot 2$ & $12 \cdot 4$ & 13.9 & $14 \cdot 4$ & $52 \cdot 3$ & $57 \cdot 1$ & $52 \cdot 4$ & $9 \cdot 6$ & $10 \cdot 4$ & $11 \cdot 0$ \\
\hline \multicolumn{16}{|l|}{ Controls } \\
\hline G.H. & $10 \cdot 3$ & $7 \cdot 9$ & 11.9 & - & 4.9 & $2 \cdot 5$ & - & $10 \cdot 3$ & 10.7 & - & 45.9 & $45 \cdot 9$ & - & - & - \\
\hline H.S. & 52.9 & $47 \cdot 2$ & $35 \cdot 4$ & $13 \cdot 4$ & $16 \cdot 3$ & $15 \cdot 5$ & 8.6 & $12 \cdot 2$ & $9 \cdot 1$ & $63 \cdot 7$ & $66 \cdot 6$ & $41 \cdot 2$ & $6 \cdot 2$ & $9 \cdot 4$ & 8.4 \\
\hline F.A. & $78 \cdot 5$ & 87.0 & $86 \cdot 1$ & $21 \cdot 0$ & $25 \cdot 3$ & $25 \cdot 6$ & $14 \cdot 7$ & $15 \cdot 1$ & 18.0 & $69 \cdot 6$ & $100 \cdot 8$ & $100 \cdot 0$ & $10 \cdot 7$ & $10 \cdot 8$ & 11.4 \\
\hline P.S. & $87 \cdot 7$ & $85 \cdot 5$ & $95 \cdot 7$ & $16 \cdot 1$ & $16 \cdot 1$ & $21 \cdot 3$ & $13 \cdot 6$ & $12 \cdot 8$ & $15 \cdot 8$ & 55.0 & $54 \cdot 5$ & $67 \cdot 6$ & 8.0 & $8 \cdot 6$ & $12 \cdot 3$ \\
\hline Mean value & $57 \cdot 4$ & 56.9 & $57 \cdot 3$ & $16 \cdot 8$ & $15 \cdot 7$ & $16 \cdot 2$ & $12 \cdot 3$ & $12 \cdot 6$ & $13 \cdot 4$ & $62 \cdot 8$ & $67 \cdot 0$ & $63 \cdot 7$ & $8 \cdot 3$ & $9 \cdot 6$ & $10 \cdot 7$ \\
\hline
\end{tabular}

In the final phase of the study the subject exercised one more time under aerobic conditions after the intravenous injection of $5 \mathrm{mg}$ edrophonium chloride (Tensilon). The drug was administered 15 seconds after the resting sample $\left(E_{0}\right)$ was drawn and 15 seconds before work commenced. Another blood sample was drawn exactly one minute after exercise began $\left(E_{1}\right)$ (Table 3$)$.

The blood samples obtained during these procedures were analysed for creatine phosphokinase (CPK), serum glutamic oxaloacetic transaminase (SGOT), serum glutamic pyruvic transaminase (SGPT), lactic dehydrogenase (LDH), and aldolase. Lactate and pyruvate levels were measured during aerobic exercise only. All assay procedures were done with a Beckman direct reading DU-2 ultraviolet spectrophotometer. All enzyme assays were done at $30^{\circ} \mathrm{C}$ and calculated in International milliunits per millilitre $(\mathrm{mu} / \mathrm{ml}$.$) . Lactate and pyruvate were$ measured on whole blood in milligrams per $100 \mathrm{ml}$.

The patients were both male and female under 65 years of age. All had a diagnosis of myasthenia gravis and attended the Myasthenia Gravis Clinic at Harper Hospital, Detroit, Michigan. The control group consisted of medical students and patients who were referred to the Department of Neurology, Wayne State University, for electromyographic studies. These studies were within normal limits and the patients did not show evidence of a myopathy or peripheral nerve disease.

Any blanks in Tables 1 to 3 represent samples in which there was insufficient blood for enzyme assay or, in a few cases, represent the termination of the procedure at the request of the subject. The large number of blanks associated with aldolase is due to the fact that a non-colorimetric method for aldolase assay was not available until this research project was well under way.

Lactate and pyruvate levels were not measured before and after ischaemic testing and before and after aerobic testing under the influence of edrophonium. The decision to eliminate these tests was based on the difficulty of assessing muscle bulk in a quantitative manner in patients and control groups. In general, the control group had much better muscle development than the myasthenic group and it was felt that this would result in misleading figures for pyruvate and lactate levels after exercise, particularly under ischaemic conditions.

\section{RESULTS}

The raw data and mean values for the three states tested-that is, (1) aerobic exercise, (2) ischaemic exercise, and ( 3 ) aerobic exercise under the influence of edrophonium chloride-are listed in Tables 1 to 3 respectively. These Tables enable one to compare patient and control group mean values. For example (see Table 1), a comparison of the mean values for lactate shows that the patient group had a mean value of $12.6 \mathrm{mg} / 100 \mathrm{ml}$. and the control group had a 
TABLE 3

SERUM ANALYSES OF SUBJECTS AT INTERVALS OF ZERO $\left(\mathrm{E}_{0}\right)$ AND ONE $\left(\mathrm{E}_{1}\right)$ MINUTE OF AEROBIC EXERCISE UNDER THE INFLUENCE OF EDROPHONIUM CHLORIDE

\begin{tabular}{|c|c|c|c|c|c|c|c|c|c|c|}
\hline \multirow[b]{2}{*}{ Subjects } & \multicolumn{2}{|c|}{$\begin{array}{c}C P K \\
(m u / m l .)\end{array}$} & \multicolumn{2}{|c|}{$\begin{array}{c}S G O T \\
(m u / m l .)\end{array}$} & \multicolumn{2}{|c|}{$\begin{array}{c}S G P T \\
(m u / m l .)\end{array}$} & \multicolumn{2}{|c|}{$\begin{array}{c}L D H \\
(m u / m l .)\end{array}$} & \multicolumn{2}{|c|}{$\begin{array}{l}\text { Aldolase } \\
(\mathrm{mu} / \mathrm{ml} .)\end{array}$} \\
\hline & $E_{0}$ & $E_{1}$ & $E_{0}$ & $E_{1}$ & $E_{0}$ & $E_{1}$ & $E_{0}$ & $E_{1}$ & $E_{0}$ & $E_{1}$ \\
\hline \multicolumn{11}{|l|}{ Patients } \\
\hline S.N. & $36 \cdot 8$ & $35 \cdot 4$ & $17 \cdot 4$ & 20.9 & $4 \cdot 2$ & $3 \cdot 4$ & $64 \cdot 0$ & $72 \cdot 6$ & $7 \cdot 1$ & $7 \cdot 1$ \\
\hline R.Z. & $15 \cdot 8$ & $9 \cdot 5$ & $7 \cdot 8$ & $12 \cdot 1$ & $10 \cdot 3$ & $11 \cdot 2$ & 3.6 & $2 \cdot 6$ & $3 \cdot 0$ & 2.9 \\
\hline R.S. & $132 \cdot 6$ & $149 \cdot 8$ & $21 \cdot 5$ & $30 \cdot 7$ & 10.5 & $10 \cdot 6$ & $88 \cdot 2$ & $74 \cdot 4$ & 11.0 & $11 \cdot 2$ \\
\hline W.E. & 236.0 & $246 \cdot 7$ & $20 \cdot 4$ & $25 \cdot 6$ & $8 \cdot 1$ & $10 \cdot 3$ & 80.7 & $70 \cdot 4$ & $11 \cdot 1$ & $14 \cdot 1$ \\
\hline J.N. & 90.6 & 93.6 & $22 \cdot 2$ & 18.9 & $17 \cdot 2$ & $15 \cdot 3$ & $55 \cdot 1$ & $55 \cdot 5$ & $10 \cdot 7$ & $13 \cdot 3$ \\
\hline G.K. & $89 \cdot 1$ & $85 \cdot 5$ & $14 \cdot 3$ & $15 \cdot 8$ & $12 \cdot 3$ & $10 \cdot 5$ & $75 \cdot 7$ & $77 \cdot 5$ & 6.9 & $7 \cdot 3$ \\
\hline G.D. & $19 \cdot 8$ & $21 \cdot 0$ & $21 \cdot 3$ & $26 \cdot 5$ & 10.9 & 16.6 & $61 \cdot 9$ & $57 \cdot 6$ & $6 \cdot 4$ & $10 \cdot 0$ \\
\hline F.S. & $16 \cdot 8$ & $12 \cdot 0$ & $30 \cdot 1$ & $30 \cdot 3$ & 36.9 & $37 \cdot 6$ & $65 \cdot 7$ & $63 \cdot 4$ & $9 \cdot 7$ & $8 \cdot 8$ \\
\hline C.P. & $54 \cdot 6$ & $69 \cdot 5$ & $22 \cdot 7$ & $26 \cdot 1$ & - & - & $61 \cdot 5$ & $77 \cdot 1$ & 13.0 & $8 \cdot 8$ \\
\hline S.B. & $6 \cdot 3$ & - & $8 \cdot 5$ & - & $7 \cdot 8$ & - & $41 \cdot 3$ & - & - & - \\
\hline J.B. & $17 \cdot 8$ & 一 & $3 \cdot 0$ & - & $5 \cdot 0$ & - & $58 \cdot 2$ & - & - & - \\
\hline E.T. & $11 \cdot 1$ & 一 & $7 \cdot 6$ & - & $7 \cdot 0$ & - & $43 \cdot 3$ & - & - & - \\
\hline C.G. & $30 \cdot 0$ & 一 & $15 \cdot 9$ & - & $9 \cdot 4$ & - & $47 \cdot 0$ & - & - & - \\
\hline M.C. & $20 \cdot 5$ & - & $7 \cdot 4$ & - & $8 \cdot 3$ & - & 52.6 & - & - & - \\
\hline W.R. & $12 \cdot 6$ & - & $10 \cdot 6$ & - & $12 \cdot 7$ & 一 & $21 \cdot 7$ & - & - & - \\
\hline Mean value & $52 \cdot 7$ & $80 \cdot 3$ & $15 \cdot 4$ & $23 \cdot 0$ & $11 \cdot 5$ & $14 \cdot 4$ & $54 \cdot 7$ & $61 \cdot 2$ & $8 \cdot 8$ & $9 \cdot 3$ \\
\hline \multicolumn{11}{|l|}{ Controls } \\
\hline G.H. & 16.6 & - & $4 \cdot 1$ & - & $9 \cdot 4$ & - & 44.9 & - & - & - \\
\hline H.S. & $35 \cdot 4$ & 30.9 & $8 \cdot 3$ & $8 \cdot 5$ & $10 \cdot 5$ & $11 \cdot 2$ & $35 \cdot 1$ & $41 \cdot 3$ & 4.9 & $6 \cdot 1$ \\
\hline F.A. & $74 \cdot 8$ & $81 \cdot 9$ & $19 \cdot 4$ & $18 \cdot 8$ & $17 \cdot 2$ & $16 \cdot 6$ & $67 \cdot 2$ & $63 \cdot 2$ & $10 \cdot 5$ & $10 \cdot 3$ \\
\hline P.S. & $105 \cdot 0$ & $90 \cdot 6$ & $19 \cdot 2$ & $20 \cdot 2$ & $14 \cdot 6$ & $12 \cdot 4$ & $77 \cdot 9$ & $57 \cdot 8$ & $10 \cdot 9$ & $11 \cdot 5$ \\
\hline Mean value & 58.0 & $67 \cdot 8$ & $12 \cdot 8$ & $15 \cdot 8$ & $12 \cdot 9$ & $13 \cdot 4$ & $56 \cdot 3$ & $54 \cdot 1$ & $8 \cdot 8$ & $9 \cdot 3$ \\
\hline
\end{tabular}

mean value of $5 \cdot 1 \mathrm{mg} / 100 \mathrm{ml}$. before aerobic exercise.

Table 4 is used to compare the average change in enzyme or metabolite level from the resting state $\left(\mathrm{E}_{0}\right)$ to the state achieved after one minute of exercise $\left(E_{1}\right)$. In the case of lactate, the average change $\left(E_{1}-E_{0}\right)$ after one minute of aerobic exercise in the patient group, was $14 \cdot 1$ $\mathrm{mg} \%$ - that is, the average patient had a $14 \cdot 1$ $\mathrm{mg} / 100 \mathrm{ml}$. increase in his lactate level after one minute of aerobic exercise. The average change in the control group was $12 \cdot 2 \mathrm{mg} / 100 \mathrm{ml}$.

In order to determine if the mean values in the patient group were statistically different from that of the control group, a difference of means test was employed. This test was run on all data and is summarized in Table 5. For example, the mean value of lactate in the aerobic resting state in the patient group was compared with that in the control group. Table 5 indicates that $\mathrm{E}_{0}$ for lactate has a confidence level of 0.99 - that is, in $99 \%$ of estimations the aerobic resting level of lactate in the patient group will differ significantly from that in the control group due to factors other than chance. A comparison of the average differences between patient and control levels after one minute of aerobic exercise $\left(E_{1}-E_{0}\right.$ in Table 5) indicates a confidence level of $0 \cdot 29$. In

TABLE 4

AVERAGE CHANGE $\left(E_{1}-E_{0}\right)$ IN ENZYME VALUE FROM RESTING LEVEL $\left(E_{0}\right)$ TO LEVEL ACHIEVED AFTER ONE MINUTE OF EXERCISE $\left(E_{1}\right)^{*}$

\begin{tabular}{|c|c|c|c|c|c|c|c|c|c|c|}
\hline & \multirow{2}{*}{\multicolumn{2}{|c|}{$\begin{array}{l}\text { Aerobic } \\
\left(E_{1}-E_{0}\right) \\
\end{array}$}} & \multicolumn{6}{|c|}{ Ischaemic } & \multirow{2}{*}{\multicolumn{2}{|c|}{$\frac{\text { Edrophonium chloride }}{\left(E_{1}-E_{0}\right)}$}} \\
\hline & & & \multicolumn{2}{|c|}{$\left(E_{3}-E_{0}\right)$} & \multicolumn{2}{|c|}{$\left(E_{10}-E_{0}\right)$} & \multicolumn{2}{|c|}{$\left(E_{10}-E_{3}\right)$} & & \\
\hline & Patient & Control & Patient & Control & Patient & Control & Patient & Control & Patient & Control \\
\hline CPK & 0.8 & $2 \cdot 0$ & $2 \cdot 3$ & -0.5 & 0.5 & -0.1 & -1.8 & -3.9 & 3.4 & -3.9 \\
\hline SGOT & 1.9 & $3 \cdot 1$ & $4 \cdot 1$ & $2 \cdot 4$ & 3.7 & $4 \cdot 0$ & -0.5 & $0 \cdot 6$ & $3 \cdot 2$ & $0 \cdot 2$ \\
\hline SGPT & 0.4 & -0.2 & $1 \cdot 3$ & $1 \cdot 1$ & $2 \cdot 0$ & $2 \cdot 0$ & $\mathbf{0} \cdot \mathbf{3}$ & $0 \cdot 1$ & 0.6 & -0.7 \\
\hline LDH & -0.5 & $8 \cdot 5$ & 4.8 & $11 \cdot 2$ & $0 \cdot 1$ & $6 \cdot 8$ & $-3 \cdot 7$ & $-3 \cdot 3$ & $-2 \cdot 1$ & -6.0 \\
\hline ALD & 4.5 & 2.5 & 0.8 & $1 \cdot 3$ & 1.4 & $2 \cdot 4$ & 0.6 & $1 \cdot 1$ & 0.5 & 0.5 \\
\hline LACT & $14 \cdot 1$ & $12 \cdot 2$ & - & - & - & - & - & - & - & - \\
\hline PYRU & 0.36 & 0.41 & - & - & - & - & - & - & - & - \\
\hline
\end{tabular}

* $E_{5}$ and $E_{10}$ indicate that blood samples were drawn 3 and 10 min after fatigue respectively. In these cases, fatigue was reached 1 min after commencement of exercise \pm 15 sec. 
TABLE 5

CONFIDENCE LEVELS OF STATISTICAL SIGNIFICANCE OF DIFFERENCES BETWEEN PATIENT AND CONTROL GROUP MEAN VALUES

\begin{tabular}{|c|c|c|c|c|c|c|c|c|c|c|c|c|}
\hline & \multicolumn{3}{|c|}{ Aerobic } & \multicolumn{6}{|c|}{ Ischaemic } & \multicolumn{3}{|c|}{ Edrophonium chloride } \\
\hline & $E_{0}$ & $E_{1}$ & $E_{1}-E_{0}$ & $E_{0}$ & $E_{3}$ & $E_{10}$ & $E_{3}-E_{0}$ & $E_{10}-E_{0}$ & $E_{10}-E_{3}$ & $E_{0}$ & $E_{1}$ & $E_{1}-E_{0}$ \\
\hline CPK & 0.01 & 0.04 & $0 \cdot 15$ & $0 \cdot 10$ & 0.01 & 0.09 & 0.44 & 0.09 & 0.25 & $0 \cdot 12$ & 0.20 & 0.74 \\
\hline SGOT & 0.54 & 0.61 & $0 \cdot 33$ & $0 \cdot 36$ & 0.39 & $0 \cdot 27$ & 0.62 & 0.09 & 0.32 & 0.45 & 0.87 & $0.95^{*}$ \\
\hline SGPT & $0.09^{*}$ & $0 \cdot 28^{*}$ & 0.31 & 0.01 & $0.26^{*}$ & $0 \cdot 15$ & $0 \cdot 14$ & 0.03 & $0 \cdot 13$ & $0 \cdot 27$ & $0 \cdot 18^{*}$ & 0.59 \\
\hline LDH & 0.92 & 0.81 & 0.66 & $0.75^{*}$ & 0.59 & 0.55 & 0.55 & 0.49 & 0.04 & $0 \cdot 10$ & 0.37 & 0.49 \\
\hline ALDOL & $0.96^{*}$ & $0.71^{*}$ & $0.53^{*}$ & 0.42 & $0.35^{*}$ & $0 \cdot 15$ & $0 \cdot 14$ & $0 \cdot 30$ & $0 \cdot 22$ & 0.50 & 0.01 & $0.02 *$ \\
\hline LACT & $0.99 *$ & 0.90 & $0 \cdot 29$ & & & & & & & & & \\
\hline PYRUV & $0.39 *$ & 0.09 & $0 \cdot 21$ & & & & & & & & & \\
\hline
\end{tabular}

* The difference of means test assumes that the patient and control groups have equal variances. When the assumption was invalid (F $>0.90$ ) a modified $t$-test was applied to control for the different variances and more accurately measure the significance of the observed mean differences.

this case, the difference between the patient value $(14 \cdot 1 \mathrm{mg} / 100 \mathrm{ml}$.) and the control value $(12.2 \mathrm{mg} / 100 \mathrm{ml}$.) is most likely due to chance.

Table 5 shows a number of situations in which differences of mean values are likely to be influenced by factors other than chance. If a confidence level of 0.95 or greater is considered to be statistically significant, there are three situations which fulfilled this criterion: (1) lactate in the aerobic resting state $\left(\mathrm{E}_{0}\right),(2) \mathrm{SGOT}$ in the aerobic state under the influence of edrophonium chloride $\left(E_{1}-E_{0}\right)$, and (3) aldolase in the aerobic resting state $\left(\mathrm{E}_{0}\right)$ :

It has already been pointed out that the mean aerobic resting level of lactate in the patient group $(12.6 \mathrm{mg} / 100 \mathrm{ml}$.) was greater than the control group $(5.1 \mathrm{mg} / 100 \mathrm{ml}$.). This difference is significant at the 0.99 confidence level.

The average increase $\left(E_{1}-E_{0}\right)$ in the SGOT value for the patient group was $3 \cdot 2 \mathrm{mu} / \mathrm{ml}$. The control group's average increase was $0.2 \mathrm{mu} / \mathrm{ml}$. (see Table 4). This difference is significant at the 0.95 confidence level. This indicates that more SGOT has passed from muscle into the serum in the patient group than in the control group.

In the case of aldolase, the mean aerobic resting level was less in the patient group $(8 \cdot 1$ $\mathrm{mu} / \mathrm{ml}$.) than in the control group $(11.0 \mathrm{mu} / \mathrm{ml}$.) (see Table 1). This difference is significant at the 0.96 confidence level.

LDH showed a mean aerobic resting level of $64.6 \mathrm{mu} / \mathrm{ml}$. for the patient group and $42.4 \mathrm{mu} /$ $\mathrm{ml}$. for the control group. The difference between these levels is significant at the 0.92 confidence level.

None of the mean values for CPK, SGPT, and pyruvate differed significantly between the two groups tested.

It is important to point out that, although some statistically significant differences do exist between patient and control group mean values, almost all the subjects' values did fall within normal limits as established by the Calbiochem Stat-Pak used in this study (see Table 6 for the normal ranges of the enzymes and metabolites

TABLE 6

RANGE OF NORMAL VALUES AT $30^{\circ} \mathrm{C}$ ACCORDING TO CALBIOCHEM TECHNIQUE

\begin{tabular}{ll}
\hline Enzyme or metabolite studied & \multicolumn{1}{c}{ Normal range $(\mathrm{mu} / \mathrm{ml}$. $)$} \\
\hline CPK & $5-60$ \\
SGOT & $5-20$ \\
SGPT & $5-24$ \\
LDH & $30-110$ \\
Aldolase & $1-6$ \\
Lactate & $5-18 \mathrm{mg} / 100 \mathrm{ml}$. whole blood \\
Pyruvate & $0 \cdot 3-0 \cdot 7 \mathrm{mg} / 100 \mathrm{ml}$. whole blood
\end{tabular}

studied). Two notable exceptions were found in the CPK determinations of patients R.S. and W.E. Their values for CPK were elevated beyond normal limits.

\section{DISCUSSION}

This study was undertaken to test the hypothesis that there may be a myopathic component in myasthenia gravis. This had been suggested by Rowland, Hoefer, and Aranow (1958) but has been somewhat obscured by the more recent concept that myasthenia gravis may be an autoimmune disease, first suggested by Simpson (1960). However, the two hypotheses are not mutually exclusive, since myositis is common in myasthenia and may have autoimmune causation (Simpson, 1960).

The presence of serum antibodies within the muscle fibre is consistent with the hypothesis that the disease is a primary muscular disorder. The higher resting level of lactate in the patient group as compared with the control group also 
supports this hypothesis, since elevated lactic acid values in blood have been reported in several muscular disorders including muscular dystrophy (Goto, Peters, and Reese, 1967).

Goto et al. (1967) measured fasting lactate levels in patients with myasthenia gravis and in several other neuromuscular diseases. This was followed by the measurement of lactate levels at 60 and 90 minutes after dextrose loading. The patient group in that study showed an average fasting lactate of $6.9 \mathrm{mg} / 100 \mathrm{ml}$. compared with the $12.6 \mathrm{mg} / 100 \mathrm{ml}$. reported here. However, the patient group in the study by Goto et al. (1967) contained two subjects. The control group of 27 subjects had an average fasting lactate level of $5 \cdot 10 \mathrm{mg} / 100 \mathrm{ml}$. This is the same value obtained in the control group of this study.

In the present study, SGOT was the only enzyme that showed a statistically significant change in the blood level after exercise. The average change in SGOT during aerobic exercise under the influence of edrophonium chloride was greater in the patient group than in the control group. This is significant at the 0.95 confidence level. In addition, the mean value of SGOT in the patient group after one minute of exercise was greater than that of the control group (see Table 3 ). This is significant at the 0.87 confidence level. These data suggest that there is increased leakage of SGOT from muscle in the patient group as compared with the control group.

Serum aldolase levels are frequently elevated in patients with primary disease of muscle. In this study, the control group had a higher mean aerobic resting value of aldolase than the patient group. Sibley and Fleisher (1954) believe that increased levels of aldolase are due to the release of this enzyme from damaged cells, the normal level being the result of physiological metabolism of cells. The reason for the higher values in the control group is difficult to explain. It is possibly due to the small sample size tested.

The recorded differences in LDH mean values are questionable at this time. Further study is necessary to determine the significance of $\mathrm{LDH}$ levels in myasthenia gravis.

The absence of differences in CPK values obtained in this study represents a significant contradiction to the hypothesis being tested. CPK levels are usually increased in myopathies, yet no significant difference in CPK values were found between myasthenics and control subjects. However, two of the patients showed abnormally elevated CPK values in all phases of the study (see Tables 1, 2, 3, patients R.S., and W.E.). This is consistent with the findings of Hess et al. (1964) who reported one myasthenic patient with an abnormal elevation of this enzyme in the serum.

\section{SUMMARY}

The enzyme levels of CPK, SGOT, SGPT, LDH, and aldolase were measured before and after exercise in patients with myasthenia gravis and in a control group. Lactate and pyruvate were also measured before and after exercise in the two groups. Both groups exercised for one minute by squeezing a sphygmomanometer bulb at the rate of one squeeze per second. Both groups exercised under (1) aerobic conditions, (2) ischaemic conditions, and (3) aerobic conditions after the injection of edrophonium chloride. The patient group showed a significantly higher resting level of lactate in the aerobic state than did the controls. In addition, the average change in SGOT values in the patient group after one minute of aerobic exercise under the influence of edrophonium chloride exceeded that of the control group. These findings suggest a possible leakage from myasthenic muscle due to a membrane defect and support the hypothesis that there is a myopathic component in myasthenia gravis. However, CPK values, which are often elevated in primary myopathies, were similar in both patient and control groups.

The nature of the pathology in myasthenia gravis is obscure. Some evidence has been presented here in favour of a primary muscle disorder. It is hoped that additional work in this area will clarify the nature of this disease which has eluded satisfactory explanation to date.

We are indebted to Miss Sandra Rovsek, Field Consultant of the Myasthenia Gravis Association of Detroit, for her help in obtaining patients for this study. Mrs. Maura Kolins helped with the computer and statistical analysis.

\section{REFERENCES}

Dameshek, W. (1965). Autoimmunity: theoretical aspects. Annals of the New York Academy of Sciences, 124, 6-28.

Downes, J. M., Greenwood, B. M., and Wray, S. H. (1966). Auto-immune aspects of myasthenia gravis. Quarterly Journal of Medicine, 35, 85-105.

Goto, I., Peters, H. A., and Reese, H. H. (1967). Pyruvic and lactic acid metabolism in muscular dystrophy, neuropathies and other neuromuscular disorders. American Journal of Medical Sciences, 253, 431-448. 
Herrmann, C. Jr. (1967). Myasthenia gravis: brief guide to diagnosis and management. California Medicine, 106, 275281.

Hess, J. W., MacDonald, R. P., Frederick, R. J., Jones, R. N., Neely, J., and Gross, D. (1964). Serum creatine phosphokinase (CPK) activity in disorders of heart and skeletal muscle. Annals of Internal Medicine, 61, 1015-1028.

Hess, J. W. (1965). Phosphorylase activity and glycogen, glucose-6-phosphate, and lactic acid content of human skeletal muscle in various myopathies. Journal of Laboratory and Clinical Medicine, 66, 452-463.

McFarlin, D. E., Engel, W. K., and Strauss, A. J. L. (1966). Does myasthenic serum bind to the neuromuscular junction? Annals of the New York Academy of Sciences, 135, 656-663.

Namba, T., and Grob, D. (1968). Myasthenia gravis. Effect of the serum and serum globulin on neuromuscular transmission. Neurology (Minneap.), 18, 273.

Perelman, L. B., and Matlina, E. S. (1957). Effect of serum from myasthenic patients on formation of phosphocreatine. Bulletin of Experimental Biology and Medicine, 44, 1352 1355.

Rowland, L. P., Hoefer, P. F. A., and Aranow, H., Jr. (1958).
Myasthenic syndromes. Research Publications of the Association of Nervous and Mental Diseases, 38, 548-600.으 Sibley, J. A., and Fleisher, G. A. (1954). The clinical signifi-Z cance of serum aldolase. Proceedings of the Staff Meetings $\$$ of the Mayo Clinic, 29, 591-603.

Simpson, J. A. (1960). Myasthenia gravis: a new hypothesise Scottish Medical Journal, 5, 419-436.

Simpson, J. A. (1966a). The biochemistry of myasthenia gravis. In Symposium über progressive Muskeldystrophie pp. 339-349. Edited by Erich Kuhn. Springer: Berlin.

Simpson, J. A. (1966b). Myasthenia gravis as an autoimmune? disease: Clinical aspects. Annals of the New York Academ,$\overline{\mathrm{N}}$ of Sciences, 135, 506-516.

Strauss, A. J. L., Seegal, B. C., Hsu, K. C., Burkholder P. M., Nastuk, W. L., and Osserman, K. E. (1960) Immunofluorescence demonstration of a muscle binding ? complement-fixing serum globulin fraction in myasthenia gravis. Proceedings of the Society for Experimental Biology음 and Medicine, 105, 184-191.

Strauss, A. J. L., and Kemp, P. G., Jr. (1967). Serum auto antibodies in myasthenia gravis and thymoma: selective affinity for I-bands of striated muscle as a guide to identifica है? tion of antigen(s). Journal of Immunology, 99, 945-953. 